\title{
Analysis of the Effect of Service Quality on Company Reputation on Purchase Decisions forProfessional Recruitment Services
}

\author{
Fernando $^{1}$, B. P. Kusumo Bintoro ${ }^{2}$, Ninda Lutfiani ${ }^{3}$, Haryanto ${ }^{4}$, Dwi Julianingsih ${ }^{5}$ \\ ${ }^{1,2}$ Universitas Bakrie Kawasan Rasuna Epicentrum, Jl. H. R. Rasuna Said No.2, RT.2/RW.5, Karet, \\ Kecamatan Setiabudi, Kuningan, Daerah Khusus Ibukota Jakarta 12940 \\ ${ }^{3,4,5}$ University of Raharja Modern, Jl. Jenderal Sudirman No.40, Cikokol, Kec. Tangerang, Kota \\ Tangerang, Banten 15117 \\ e-mail: admisi@bakrie.ac.id ${ }^{1}$, kusumo.bintoro@bakrie.ac.id ${ }^{2}$, ninda@ $@$ raharja.info $^{3}$, \\ haryanto@raharja.info ${ }^{4}, \underline{\text { dwi.julianingsih@raharja.info }}{ }^{5}$
}

\section{Article Info}

Article history:

Received 14-12-2021

Revised 29-12-2021

Accepted 1-1-2023

\section{Keywords:}

Company reputation

service quality

purchase decision

headhunter

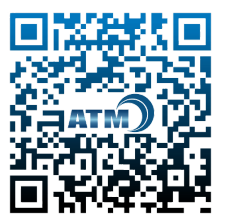

\section{Corresponding Author:}

Dwi Julianingsih

University of Raharja, Tangerang, Indonesia

Email: dwi.julianingsih@raharja.info

\begin{abstract}
PT)
This study aims to analyze the effect of company reputation and service quality on purchasing decisions for headhunter services. This study is to determine the basis for consumer considerations in choosing a headhunter company, and for headhunter companies this research can be a reference in maintaining relationships with their customers. There are 3 hypotheses tested, and this study uses quantitative methods by conducting surveys. The sampling method is using probability sampling with a sample size of 115 respondents based on the hair formula. As for analyzing the data of this study using multiple linear regression analysis methods. The company's reputation and service quality both influence the decision to purchase headhunter services, with the main factor having higher relevance being the service quality variable. This study aims to determine the relationship of company reputation and service quality to purchasing decisions on professional recruitment services. Future research is expected to raise one case from a large headhunter company (local/international) regarding building the reputation of a headhunter service company. This is so that the headhunter Industry has a proven academic subject of what reputation looks like in the Headhunter Industry.
\end{abstract}

This is an open access article under the CC BY 4.0 license.

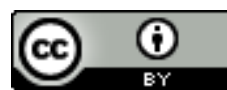

\section{INTRODUCTION (10 PT)}

One of the biggest challenges for an organization/company is finding the best talent in the labor market. In today's labor market, there is a very massive labor movement. This displacement, in most cases, occurs due to the intervention of the headhunter. Headhunters are part of a third-party relationship between clients and candidates with unique talents and the best in their fields[1].

Headhunter has become a recognized profession by job seekers. Headhunters generally provide job opportunities for a professional level or "white collar" with management level or Board of Director level criteria. Headhunter firms generally have many databases with specifications for candidates/talents with specific qualifications. This database is a valuable business asset for headhunter companies[2].

Skills largely determine the success of a headhunter as a profession in enhancing and managing a reputation as an elite professional labor market broker[3]. The life and death of a headhunter firm are determined by its ability to manage its reputation. Harvey further explained that headhunters are a category of 
Professional Service Firms (PSFs), where reputation is an organization's evaluation based on the perceptions of various stakeholders. Reputation is essential and essential in many types of service industries for PSFs[4].

In the professional recruitment service industry or headhunters, company reputation and service quality are essential in maintaining customer trust. Over time, business competition between companies is getting tougher[5]. Each company is vying to win the competition. They are increasingly competitive and strive to provide the best service and maintain an excellent name to survive in the competition, maintain relationships with clients and achieve profits[6][7].

Reputation is the most critical factor of the company's characteristics that can form customer trust.[8] Boyd \& Bergh added that the company's reputation is an intangible asset that can maintain a company's competitive advantage sustainable[9]. However, building a company's reputation takes a long time. The more positive the company's reputation, the more financially profitable it will be[10].

In order to maintain the continuity of a business, especially in the service industry, a company must be able to provide the best service to its clients consistently to improve its reputation and provide a competitive advantage in business competition with competitors[11].

Based on the description above, this study aims to determine the effect of company reputation and service quality (Headhunter) on purchasing decisions for professional recruitment services[12].

\section{THE COMPREHENSIVE THEORETICAL BASIS}

This research is a type of quantitative research. Sugiyono, quantitative research is used to examine the population and samples[13]. The sampling technique is generally done randomly or randomly. Collecting data using research instruments, data analysis is statistical, which aims to test specific hypotheses. [14] The research method was carried out to see the relationship between the two variables. In this study, the variables are the dependent and independent variables[15].

\subsection{Formula/Algorithm [optional]}

This study has two types of variables: independent and dependent variables. The independent variables in this study are the company's reputation and service quality. Meanwhile, the dependent variable in this study is the decision to purchase professional recruitment services (headhunters)[16].

Table 3. 1 Table of Operational Variables

\begin{tabular}{|c|c|c|c|c|}
\hline Variabel & Dimensi & Indikator & Deskripsi & Skala \\
\hline \multirow{4}{*}{$\begin{array}{l}\text { Company } \\
\text { Reputatio } \\
\text { n (X1) }\end{array}$} & \multirow[t]{3}{*}{$\begin{array}{l}\text { Emotional } \\
\text { Appeal }\end{array}$} & Feel good about & Feelings of liking the company & Likert \\
\hline & & $\begin{array}{l}\text { Admire \& } \\
\text { respect }\end{array}$ & $\begin{array}{l}\text { Admire \& appreciate the } \\
\text { company }\end{array}$ & Likert \\
\hline & & Trust & Trust in the company & Likert \\
\hline & $\begin{array}{l}\text { Product \& } \\
\text { Service }\end{array}$ & Stands behind & $\begin{array}{l}\text { Products \& services according to } \\
\text { company identity }\end{array}$ & Likert \\
\hline
\end{tabular}




\begin{tabular}{|l|l|l|l|}
\cline { 2 - 4 } & $\begin{array}{l}\text { Offer high } \\
\text { quality }\end{array}$ & $\begin{array}{l}\text { The company offers high } \\
\text { quality products \& services }\end{array}$ & Likert \\
\hline
\end{tabular}

\begin{tabular}{|c|c|c|c|c|}
\hline & & $\begin{array}{l}\text { Develops } \\
\text { innovative }\end{array}$ & $\begin{array}{l}\text { The company is always } \\
\text { innovating }\end{array}$ & Likert \\
\hline & & Offer good value & $\begin{array}{l}\text { The company offers high } \\
\text { quality products \& services }\end{array}$ & Likert \\
\hline & \multirow[t]{3}{*}{$\begin{array}{l}\text { Vision \& } \\
\text { Leadership }\end{array}$} & $\begin{array}{l}\text { Has Excellent } \\
\text { Leadership }\end{array}$ & $\begin{array}{l}\text { The company has a reliable } \\
\text { leader }\end{array}$ & Likert \\
\hline & & $\begin{array}{l}\text { Has a clear } \\
\text { vision for the } \\
\text { future }\end{array}$ & $\begin{array}{l}\text { The company has a } \\
\text { clear vision for the } \\
\text { future }\end{array}$ & Likert \\
\hline & & $\begin{array}{l}\text { Recognize/takes } \\
\text { advantage of } \\
\text { marketing } \\
\text { opportunity }\end{array}$ & $\begin{array}{l}\text { Companies are able to find and } \\
\text { take advantage of existing } \\
\text { opportunities }\end{array}$ & Likert \\
\hline & \multirow[t]{3}{*}{$\begin{array}{l}\text { Workplace } \\
\text { Environment }\end{array}$} & Well managed & The company is well managed & Likert \\
\hline & & $\begin{array}{l}\text { Look like a good } \\
\text { company to } \\
\text { work for }\end{array}$ & $\begin{array}{l}\text { Company looks like a } \\
\text { good place to work }\end{array}$ & Likert \\
\hline & & $\begin{array}{l}\text { Look like has a good } \\
\text { employees }\end{array}$ & $\begin{array}{l}\text { The company seems to have } \\
\text { professional } \\
\text { employees/workers in their } \\
\text { fields }\end{array}$ & Likert \\
\hline $\begin{array}{l}\text { Service } \\
\text { Quality } \\
\text { (X2) }\end{array}$ & & Reliability & $\begin{array}{l}\text { Work consistency \& ability to } \\
\text { be trusted }\end{array}$ & Likert \\
\hline
\end{tabular}




\begin{tabular}{|c|c|c|c|}
\hline & Responsiveness & $\begin{array}{l}\text { Ability and readiness to } \\
\text { provide services that } \\
\text { customers need }\end{array}$ & Likert \\
\hline & Tangible & $\begin{array}{l}\text { Physical representation of } \\
\text { services }\end{array}$ & Likert \\
\hline & Assurance & $\begin{array}{l}\text { Knowledge, courtesy and } \\
\text { trustworthy }\end{array}$ & Likert \\
\hline & Empathy & $\begin{array}{l}\text { Ease of building relationships, } \\
\text { good communication, caring and } \\
\text { understanding customer needs }\end{array}$ & Likert \\
\hline \multirow[t]{4}{*}{$\begin{array}{l}\text { Buying } \\
\text { decision } \\
\text { (Y) }\end{array}$} & $\begin{array}{l}\text { Need/problem } \\
\text { recognition }\end{array}$ & $\begin{array}{l}\text { Recognizing the desired } \\
\text { state with the actual } \\
\text { situation }\end{array}$ & Likert \\
\hline & $\begin{array}{l}\text { Information } \\
\text { search }\end{array}$ & $\begin{array}{l}\text { The search for a decisive } \\
\text { solution }\end{array}$ & Likert \\
\hline & $\begin{array}{l}\text { Alternative } \\
\text { Evaluation }\end{array}$ & $\begin{array}{l}\text { Evaluate options to narrow the } \\
\text { choice to the desired alternator }\end{array}$ & Likert \\
\hline & $\begin{array}{l}\text { Purchase } \\
\text { Decision }\end{array}$ & $\begin{array}{l}\text { Make a purchase based on } \\
\text { the chosen alternative }\end{array}$ & Likert \\
\hline
\end{tabular}

\begin{tabular}{|l|l|l|l|l|}
\hline & $\begin{array}{l}\text { Post-purchase } \\
\text { behaviour }\end{array}$ & $\begin{array}{l}\text { Are satisfied or } \\
\text { dissatisfied post- } \\
\text { purchase } \\
\text { (Post purchase dissonance) }\end{array}$ & Likert \\
\hline
\end{tabular}

\subsection{Literature Review}


The data analysis method used in this research is the multiple linear regression method. Multiple linear regression analysis provides facilities to objectively assess the degree and character of the relationship between the independent and dependent variables. The influence between variables in this study can be known using the SPSS (Statistical Package for the Social Science) application. The form of the equation of the path is as follows:

$\mathrm{Y}=\operatorname{pyx} 1+$ pyx $2+$ pyxk $+\varepsilon$

$\mathrm{Y}=$ Service purchase decision (endogen)

$\mathrm{X} 1, \mathrm{X} 2=$ Effect of company reputation and service quality $\mathrm{P}=$ Path coefficient between causal variables and effect variables $\varepsilon=$ Variabel residu (error)

\section{Result and Discussion}

In this study, the population is the clients of the consulting firm Headhunter X in Jakarta; the author proposes a set of questionnaires to the respondents totaling 115 people. This questionnaire consists of several statements representing the three variables studied. The three research instruments in a questionnaire are instruments about company reputation, service quality, and purchasing decisions. The company reputation variable questionnaire consists of 13 statement items. Service quality consists of 5 statement items and the variable. The purchase decision consists of 5 statement items. The results or data obtained from questionnaires that respondents have filled out are then entered or processed by SPSS software (Statistical Program Social Science)[17].

\subsection{Literature Review}

Testing the validity and reliability in this study used the SPSS (Statical Package for the Social Science) version 22 application to calculate the correlation between each answer item and the total score. To measure whether the instrument is valid or not, it is done by comparing the calculated correlation number with the critical number in the correlation table for the r-value with a confidence level of 95 percent. Then the calculated $r$ is compared with the $r$ table, with the following decision criteria:

- If $r$ count $>r$ table, it means that the research instrument is valid

- If $r$ count $<r$ table, it means the research instrument is not valid

Instrument reliability shows that an instrument can be trusted as a consistent measuring tool in data collection. The instrument can be trusted if the calculated $r$-value is greater than the table $r$ table. The value of the instrument reliability test results can also be grouped into:

- Less reliable with Cronbach's Alpha coefficient (0.00-0.20)

- Somewhat reliable with Cronbach's Alpha coefficient (0.21-0.40)

- Quite reliable with Cronbach's Alpha coefficient (0.41-0.60)

- Reliable with Cronbach's Alpha coefficient (0.61-0.80)

\section{RESULTS AND DISCUSSION}

This study aims to determine the relationship of company reputation and service quality to purchasing decisions on professional recruitment services. Based on the analysis of the variables used, the following conclusions were drawn: First, of the 13 forming factors of the independent variable (X1), eleven forming factors influence customer purchasing decisions in using headhunter services. At the same time, the other two independent variable factors can be ignored because their statements are vague, namely admiration and interest. Second, the five factors that make up the independent variable Quality of Service (X2) affect customers' purchasing decisions when using headhunter services. Third, Five factors form the dependent variable on purchasing decisions ( Y) has a strong correlation with the independent variables Company reputation \& service quality, but the dominance with the most decisive influence is service quality.

\section{Suggestion}

Based on the results of this study, some recommendations can be applied both practically and academically. The practical recommendations are:

1. Headhunter companies are expected to improve the best service to provide a good image/reputation to clients because the nature of service companies is service and how to give satisfaction to customers/clients[18].

2. Headhunter companies, besides having an obligation to provide the best service to clients, another thing is to maintain the good name of the candidates who have been processed, because these candidates can indeed become influencers who give a positive impression to clients or other companies[19].

While the academic recommendations are: 
1. Future research is expected to raise one case from a large headhunter company (local/international) regarding building the reputation of a headhunter service company[20]. This is so that the headhunter Industry has a proven academic subject of what reputation looks like in the Headhunter Industry[21][22].

2. Further research that can be exposed is looking at the point of view of candidates who have experienced the services of the headhunter industry so that we can academically see clearly what it is like to build a company reputation from the perspective of clients and candidates[23].

\section{REFERENCES}

[1] W. S. Harvey, J. V Beaverstock, and H. Li, "Common threats and managing reputation in executive search firms," Br. J. Manag., vol. 30, no. 4, pp. 847-868, 2019.

[2] M. Yazdanpanah and F. R. Feyzabad, "Investigating Iranian farmers' satisfaction with agricultural extension programs using the American customer satisfaction index," J. Agric. Food Inf., vol. 18, no. 2, pp. 123-135, 2017.

[3] K. Kumagai, "Sustainable plastic clothing and brand luxury: a discussion of contradictory consumer behaviour," Asia Pacific J. Mark. Logist., 2020.

[4] F. S. T. Istiakroh, "PENGARUH KOMUNIKASI TERHADAP PELAYANAN PRIMA KEPADA MASYARAKAT DI KANTOR LURAH BUKUAN," Adm. PUBLIK, vol. 1, no. 2, pp. 61-65, 2018.

[5] K. Podnar and U. Golob, "The quest for the corporate reputation definition: Lessons from the interconnection model of identity, image, and reputation," Corp. Reput. Rev., vol. 20, no. 3, pp. 186-192, 2017.

[6] N. Antoniades and I. Mohr, “Strengthening US Politicians' Reputation,” Society, vol. 57, no. 1, pp. 41-52, 2020.'

[7] D. Apriani, A. Williams, U. Rahardja, A. Khoirunisa, and S. Avionita, "The Use of Science Technology In Islamic Practices and Rules In The Past Now and The Future,” Int. J. Cyber IT Serv. Manag., vol. 1, no. 1, pp. 48-64, 2021.

[8] M. De Mooij, Consumer behavior and culture: Consequences for global marketing and advertising. Sage, 2019.

[9] K. Arora and A. S. Bist, "Artificial intelligence based drug discovery techniques for covid- 19 detection," Aptisi Trans. Technopreneursh., vol. 2, no. 2, pp. 120-126, 2020.

[10] T. N. Krishnan and H. Scullion, "Talent management and dynamic view of talent in small and medium enterprises," Hum. Resour. Manag. Rev., vol. 27, no. 3, pp. 431-441, 2017.

[11] C. E. Carroll, “Corporate reputation and the news media: The origin story,” Corp. Reput. Rev., vol. 20, no. 3, pp. 165-170, 2017.

[12] J. Cornelissen, Corporate communication: A guide to theory and practice. Sage, 2020.

[13] A. S. Bein, Y. I. Graha, and A. P. Pangestu, "Pandawan Website Design Based Content Management System As Media E-commerce Transaction,” Aptisi Trans. Technopreneursh., vol. 2, no. 1, pp. 87-97, 2020.

[14] A. S. Anwar, U. Rahardja, A. G. Prawiyogi, and N. P. L. Santoso, "iLearning Model Approach in Creating Blockchain Based Higher Education Trust," Int. J. Artif. Intell. Res., vol. 6, no. 1, 2022.

[15] U. Rahardja, A. N. Hidayanto, P. O. H. Putra, and M. Hardini, "Immutable Ubiquitous Digital Certificate Authentication Using Blockchain Protocol," J. Appl. Res. Technol., vol. 19, no. 4, pp. 308-321, 2021.

[16] W. Setyowati, P. C. Kurniawan, A. Mardiansyah, E. P. Harahap, and N. Lutfiani, “The Role Of Duty Complexity As A Moderation Of The Influence Auditor's Professional Knowledge And Ethics On Audit Quality," Aptisi Trans. Manag., vol. 5, no. 1, pp. 20-29, 2021.

[17] A. K. Badri, J. Heikal, Y. A. Terah, and D. R. Nurjaman, "Decision-Making Techniques using LSTM on Antam Mining Shares before and during the COVID-19 Pandemic in Indonesia,” APTISI Trans. Manag., vol. 6, no. 2, pp. 167-180, 2022.

[18] Q. Aini, E. P. Harahap, and F. Faradilla, “The Effects of Sales Reports Business Intelligence on Employee Performance,” Aptisi Trans. Manag., vol. 4, no. 1, pp. 83-91, 2020.

[19] I. K. Subagja and P. H. Susanto, "Pengaruh Kualitas Pelayanan, Kepuasan Nasabah Dan Citra Perusahaan Terhadap Loyalitas Nasabah Pt. Bank Central Asia Tbk Kantor Cabang Pondok Gede Plaza,” J. Manaj. Bisnis Krisnadwipayana, vol. 7, no. 1, 2019.

[20] A. D. Saputra, R. Nurmala, and A. P. Cakrawala, "Penerapan Strategi Pemasaran 8p Terhadap Peningkatan Omset Penjualan Pada Warung Marso Malang,” J. Eksek., vol. 15, no. 1, pp. 19-41, 2018.

[21] G. H. Hanson and M. J. Slaughter, 12. High-Skilled Immigration and the Rise of STEM Occupations in US Employment. University of Chicago Press, 2019.

[22] L. Rossoni and W. Mendes-Da-Silva, "How does legitimacy operate in emerging capital markets? Investigating the moderating 
effects of premium listings and firm size on risk," Can. J. Adm. Sci. Can. des Sci. l'Administration, vol. 36, no. 3, pp. 404-417, 2019.

[23] K. Bista, "Exploring the field: Understanding the international student experience," in Global Perspectives on International Student Experiences in Higher Education, Routledge, 2018, pp. 1-15. 